Анастасія Віталї̈вна Варивончик, кандидат мистецтвознавства, доцент, Київський університет ім. Б. Грінченка

\title{
ПОРЦЕЛЯНА В КОНТЕКСТІ ХУДОЖНІХ ПРОМИСЛІВ УКРАЇНИ
}

Одним із найвитонченіших різновидів кераміки є пориеляна. Стаття присвячена особливостям розвитку изього мистецтва в контексті художніх промислів України та подальший розвиток виробництв які виготовляли вироби з пориеляни.

Ключові слова: пориеляна, орнамент, декор, глина, випал.

Одним из самых утонченных разновидностей керамики как известно, является фарфор. Статья посвящена особенностям развития этого искусства в контексте художественных промыслов Украины и дальнейшее развитие производств которье изготовляли изделия из фарфора.

Ключевье слова: фарфор, орнамент, декор, глина, обжиг.

One of the most sophisticated varieties of ceramics is porcelain. The article focuses on the evolution of this art in the context of the arts and crafts of Ukraine and further development of industries which were made of porcelain.

Key words: porcelain, ornament, decor, clay, firing.

Про традиційне народне мистецтво загалом та його різні галузі, види і різновиди зокрема існує значний корпус наукових досліджень. Так, про мистецтво вишивання писали Л. Кравчук (1969), М. Новицка (1972), Т. Кара-Васильєва (1993, 2000). Вишивання в усіх його різновидах як поширений вид народної творчості ретельно проаналізувала Р. Захарчук-Чугай (1988), С. Причепій (2009) та ін. Подібно виглядає справа і щодо такого різновиду народного мистецтва, як домашнє ткацтво. Його досліджували С. Колос (1928), Н. Лєбєдєва (1956), С. Сидорович (1979), А. Карась (2013). Багатовікові історичні та технологічні традиції українського килимарства вивчали: Д. Щербаківський (1927), С. Таранущенко (1968), А. Жук (1973), Я. Запаско (1973), Т. Кара-Васильєва (1997), О. Данченко (1982) та ін. Деревообробку на Україні досліджували: М. Селівачов (1985), С. Антонович, Р. Захарчук-Чугай, М. Станкевич (1992), Е. Шевченко (1997), М. Селівачов (2002). Гончарство і кераміку вивчали: А. Арциховский (1947), А. Августиник (1957); П. Будников (1962); У. Кинджери (1967); Н. Воронов (1973), О. Голубец (1984, 1991), В. Петрашенко (1992), О. Пошивайло (1993), В. Качкан (1994), Ю. Лащук (1998), І. Пошивайло (2000), В. Міщанин (2006). Мистецтво декоративного розпису досліджували Н. Велігоцька (1938), Б. БутнікСіверський (1977), Я. Яценко, В. Соловйов (1982), В. Свенціцька, В. Откович (1991), Т. Голяк (1999), Л. Білякова (2000), Т. Кара-Васильева, З. Чегусова (2005), про мистецтво фарфору-фаянсу писало: Н. Теодорович (1888), Б. Бутнік-Сіверський (1972), Т. Кара-Васильєва (1984), Л. Федевич (2006), О. Школьна (2011), В. Костуш (2011), 
А. Зкурлат (2011). Видання та публікації про гутне скло здійснили Ф. Петрякова (1975), Й. Ящишин, Т. Жеплинський, С. Дяківський (2004). Також були дослідженні та захищені кандидатські дисертації за темами художніх промислів України: Г. Івашків (2004), В. Дутка (2007), О. Дяків (2007), О. Луковська (2007), В. Андріяшко (2009), А. Радченко (2009), Л. Семчук (2009).

У цих та інших публікаціях даної тематики йдеться про зміст, особливості образної структури, про майстерність умільців, про традиції, зокрема й родині тощо. Але мало хто 3-поміж авторів, навіть тих, у назвах праць котрих міститься термін «промисел», звертає увагу саме на виробничий, промисловий аспект народної творчості, хоча згадані, як і інші, не названі тут, традиційні народні мистецтва здавна називаються художніми промислами. Цим і зумовлений вибір теми дослідження: художні промисли України.

Мета статті - висвітлити обставини появи та відстежити історичну еволюцію на території України унікального художнього промислу - виготовлення виробів 3 порцеляни (фарфору).

Термін «порцеляна» пояснюється по-різному. Зовнішній вигляд порцеляни, вироби з якої були завезені з Китаю, нагадував європейцям морську мушлю. В Італії набула назву «порчелла», відтак посуд китайського походження нібито дістав назву «порчелан» [3, с. 175]. Це достоту нагадує подібні вигадки про походження терміна бароко: з огляду на особливості цього стилю («вигадливий», «примхливий», «розвельможений» тощо) людський поговір приписав подібне значення і самому слову. Тим часом, як слово «бароко» означає трохи змінене вимовляння прізвища основоположника цього стилюФедеріко Бароккіо. Насправді слово пориеляна китайського походження, як і вироби 3 неї, і в перекладі означає «обпалена земля»: таку назву отримали природні зразки цього матеріалу, вперше віднайдені на місцях згаслих вулканів [5]. Минуло чимало років, поки допитливий китайський розум докопався до таємниці природного творення цього матеріалу і започаткував виробництво цього незвичайного різновиду кераміки. Чимало часу спливло поки в Європі, зачарованій красою цих виробів, також розгадали цей китайський секрет і налагодили власне виробництво порцеляни, вироби з якої мали різні назви в залежності від місця та способу виготовлення (поєднання білої глини з іншими мінеральними додатками, зокрема окислами неорганічних сполук) - фарффор ( тур. fağfur fagfur, від перс. Faghfur) фаянс (фр. faience, від назви італійського міста Фаенца). Для розрізнення використовуються й інші критерії: з фарфору виробляються головним чином предмети хатнього вжитку, переважно посуд, 3 фаянсу - здебільшого, облицювальні плитки, архітектурні деталі, вироби санітарно-гігієнічного призначення.

На Україні виробництво порцеляни розпочалося наприкінці XVIII ст. Одна з перших мануфактур була заснована у місті Корець Рівненський області, поблизу якого, у селі Домбрувка, виявилося родовище глини (каоліну). Основним видом продукції були різні фігурки та столовий посуд. Невдовзі від початку виробництва (1796 р.) сталася пожежа [10] і на відновлення мануфактури знадобилася третина століття - 31800 по 1832 pp. Основним видомпродукції стало виготовлення плитки, для облицювання фасадів [6, с. 913].

Тимчасом (з 1807 р.) запрацювала мануфактура і в сусідній Житомирській області (село Городниця), на оснащенні якої було аж сім обпалювальних агрегатів: дві «фарфорові» та п’ять «фаянсових» печей. На річці Случ працював водяний млин, якому 
здійснювалася підготовка сумішей для виготовлення сировини. Наприкінці 50-х рр. XIX ст. було освоєно виготовлення виробів амфоро подібної форми. На поч. XIX ст. виробництво згоріло в пожежі [6, с. 913].

Майже одночасно з Городницькою запрацювала у Житомирській області й друга мануфактура порцелянового виробництва - у містеку Баранівка. Вироби Баранівського підприємства (столовий посуд, вази) відзначалися високою якістю, користувалися широким попитом та експонувалися на міжнародних виставках: у Венеції (1910р.), Римі (1911 р.), Барселоні (1913 р.), Лондоні (1913-1914 рр.) [6, с. 913].

Із 1917 р. на Баранівському уже заводі переважає «радянській стиль». Майже вся продукція підприємства - тарілки, сервізи, чашки, статуетки та вази позначені «революційною» символікою: зображення «Серпа і Молота», робітників і селян, червоні прапори та зірки.

Після Другої світової війни асортимент продукції на Баранівському заводі помітно збагатився виробництвом спортивних кубків, різноманітного посуду та оригінальної форми «доповненнями»: маслянки, пудрениці, сувенірні скриньки, настільні скульптурки. Славна історія Баранівського фарфорового заводу закінчилася 2010 р.: підприємство було визнане банкрутом і ліквідовано [2].

У XVIII ст. започатковано також осередок розвитку порцелянового виробництва поблизу Києва: Межигір'ї, неподалік від якого було віднайдено родовище придатної глини [7, с. 400].

У XIX ст. виробництво порцеляни поширюється далі на східні регіони України. Перший порцеляновий завод з'являється у Сумській області - у селі Волокитине, поблизу якого було відкрите Полошкинске родовище каоліну. Його заснував на території свого родового маєтку Чернігівський поміщик Андрій Михайлович Міклашевский. Підприємство розташовувалося у двох корпусах. В одному з них на першому поверсі розміщувалися верстати для обробки виробів, полиці для просушування, гіпсові форми, на другому - майстерня для розпису порцеляни. У другому корпусі були встановлені жорна для помолу, облаштовані «манежі», сушильна камера. Поряд знаходився муфельний горн (муфельна піч). Муфельна піч - нагрівальний пристрій, призначений для нагрівання різноманітних матеріалів до певної температури $[12$, с. 31$]$.

Продукція заводу Міклашевського здобуває визнання професіоналів: удостоюється Великої срібної медалі на мануфактурній виставці «Мистецтво кращих фарфорових речей», на виставці 1849 р. Міклашевського - Великої золотої медалі. Та особливої слави здобув завод і його власник за іконостас, виготовлений для Волокитинської церкви св. Покрови. Цей коштовний витвір став одним із найважливіших етапів розвитку порцелянової справи на території України в сер. ХІХ ст. [12, с. 31].

Наприкінці XIX ст. розпочинає свою діяльність великий фаянсовий завод у Будах під Харковом, який належав родині Кузнєцових. Тут було налагоджено випуск полумисків, кухлів, барилець, тарілей, прикрашених квітами, півниками. Саме тут було вперше налагоджено художній друк для оформлення виробів [3, с. 175].

Після революції 1917 р. докорінно змінилися умови розвитку культури і мистецтва. Порцелянові підприємства були одержавлені, і вироби перших пореволюційних років увійшли в історію як твори бойової тематичної агітації. 
До 1927 р. збут порцелянової продукції потребував додаткових важелів впливу на свідомість мас споживачів, на їхні смаки та вподобання. Вимогою часу був пошук шляхів створення власного торговельного апарату, зважаючи на широкий асортимент виробів, який потребував розвинутої мережі оптово-роздрібних баз [7, с. 400]. У 20-х pp. XX ст. Межигір'я стає форпостом відродження освіти у галузі промислової кераміки. Його створення передбачалося здійснити поетапно: організація лабораторії фарб і деколей; створення експериментального цеху розпису, де б здійснювалися експерименти з декоруванням фарфору і виготовлення одиничних примірників виставкових робіт; а в перспективі - запуск експериментального керамічного заводу в Києві з цехами виробництва фарб, друку, деколі та цеху порцеляни, розрахованим на масове тиражування. У Межигір”ї, розробляли проекти та плани облаштування експериментальних художніх майстерень при Главку Укрфарфорфаянстресту в Києві [7, с. 400].

У 1925-1927 pр. на Правобережній Україні було створено трест «Фарфор - ФаянсСкло», до компетенції якого було віднесено, крім усього іншого, виготовлення та поширення реклами на продукти фарфоро-фаянсового виробництва. У тресті та його підвідомчих підприємствах і установах було задіяно до п'яти з половиною тисяч працівників. Підприємства, об'єднані у тресті, виробляли «фарфоровий та фаянсовий посуд», «ізоляційний фарфор», «санітарний фаянс», «сортове скло», трест мав допоміжні виробництва - кар'єри для видобутку глин та каоліну, майстерню фарб. Трест вважався організацією загальносоюзного масштабу: правління його містилось у Києві, а контори у Харкові та Москві [7, с. 400].

У червні 1925 р. у лабораторії фарб і деколі тресту було започатковано художню секцію. Співробітникам цього підрозділу доручалося вирішити питання щодо розписів виробів із фарфору та фаянсу, а також механізації та напрацювання нових зразків рисунків для декорування.

У 30-х рр. ХХ ст. назва виробництва кілька разів змінювалася й врешті звучала як «Київська фабрика фарб». У 1936 р. у Києві створюється завод дослідної художньої кераміки, що розробляв для фарфоро-фаянсових підприємств нові форми й зразки художнього розпису, та експериментальний керамічний завод Укрфарфору. [7, с. 400].

Після війни у розпорядженні тресту перебували науково-дослідна лабораторія та цілий ряд заводів: сім фарфорових (Баранівка, Городниця, Полонне, Довбиш, Коростень, Оленівськ, Токаревка), один фаянсовий (Буди). Також на балансі тресту знаходилися 16 «скляних» і «склотарних» підприємств, Житомирська дзеркальна фабрика, майоліки (у Василькові), дослідний Київський експериментальний кераміко-художній завод (на колектив якого було покладено проектування форми, варіанти розпису, деколі для всієї галузі), а також фірмовий магазин. Пізніше до цього переліку додалися реформовані артілі, відбудовані заводи та зведені нові виробничі комплекси.

До порцелянового виробництва залучаються народні майстри з Петриківки, які переносять свої візерунки та малюнки на промислові вироби. Петриківський розпис застосовують для прикрашування великогабаритних ваз, які завдяки цьому стають мало не в ряд зі скульптурним оздоблення простору громадського призначення. Характерні риси тематичних картин, прояви станковізму, що набувають дедалі більшого застосування у порцеляновому українському виробництві, пов'язані саме 3 петриківським розписом, який з кін. 40-х рр. ХХ ст. застосовується в різних видах 
художньої творчості. Водночас під впливом мистецтва «старшого брата» його наближують до палехського і хохломського розпису: запроваджують чорне лакове тло.

Усі виробництва у цей час підпорядковувалися Українському республіканському тресту «Укрфарфорфаянс». Київський главк почав працювати з кінця 1943 р., $з$ грудня поновлено роботу на Київському експериментальному кераміко-художньому заводі.

Деякі заводи відбудувалися заново, сировинно-виробничі зв'язки фактично утворювали окрему галузь. Трест здійснював роботи із відновлення знищених i пошкоджених порцелянових, фаянсових, скляних заводів, налагоджував зв'язки 3 організаціями будівельників, фахівців із паливно-енергетичного комплексу, видобутку інгредієнтів мас, компонентів полив; відновлював роботи з випуску фарб, золота, деколей для підпорядкованих підприємств [1, с. 232].

Підготовкою професійних кадрів для всієї галузі здійснював єдиний такого профілю мистецький навчальний заклад - Львівський інститут прикладного i декоративного мистецтва.

Після 1945 р. істотних змін зазнала стилістика українських тонко керамічних виробів. Поступово відбувалися трансформації типології, набували нових рис художні частини окремих виробництв, що ставали «впізнаваними», як колись дореволюційні Пациків, Миргород, Коломия та Баранівка.

Український республіканський трест фарфоро-фаянсової промисловості «Укрфарфорфаянс» (до поч. 70-х рр. ця установа містилася у центрі Києва, на вул. Червоноармійській, 133-135) був орієнтований не лише на внутрішній ринок, а й на експорт, ставилися завдання надолужити всі втрати попередніх років і ліквідувати дистанцію у смакових, модних і виробничо-технологічних орієнтирах між СРСР і країнами, орієнтованими на розвиток за капіталістичним типом.

Проте у червні 1957 р. сталася чергова адміністративно-бюрократична реорганізація, в ході якої було ліквідовано 10 загальносоюзних і 15 союзнихреспубліканських міністерств, у тому числі й українське Міністерство місцевої промисловості. Підпорядковані раніше йому підприємства було передано до складу 11 Рад народного господарства (Буди, а згодом Полтава за архівними даними Харківського Раднаргоспу, а заводи Волинської групи - Київського Раднаргоспу). На базі структурних частин ліквідованого Главку в столиці було утворено Управління фарфоро-фаянсової і місцевої промисловості, яке здійснювало безпосереднє управління підприємствами фарфоро-фаянсовою і скляною промисловістю Київського економічного адміністративного району [7, с. 400].

У 1966 р. Раднаргоспи були ліквідовано, заводи лишалися у відомстві Управління фарфоро-фаянсової промисловості УРСР. Із 1970 р. підприємства підпорядковувалися Республіканському виробничому об'єднанню фарфоро-фаянсової промисловості Міністерства легкої промисловості УРСР. Із 1975 р. нову структуру Укрфарфорфаянсу почали також скорочено називати «Укрпромфарфор» (паралельно продовжували вживатися обидві назви).

У 1976 році зафіксовано приналежність заводів Українському промисловому об'єднанню з виробництва фарфорових і фаянсових виробів «Укрпромфарфор». У 1989 р. заводи стали підпорядковуватися Управлінню розвитку фарфоро-фаянсової промисловості, фурнітури та іграшки Міністерства легкої промисловості УРСР. На поч. 1990-х рр. це структурне управління поступово розпалося й було ліквідовано. Весь 
архів організації Укрпромфарфор, що знаходився на другому поверсі магазину «Фарфор-фаянс» на Хрещатику в Києві, було втрачено.

Важливо, що у др. пол. ХХ століття мистецький рівень продукції вітчизняних тонко керамічних заводів постійно зростав, розвивався єдиним організмом, відбувався планомірний підйом галузі. Фарфор-фаянс України 1950-х - 2000-х (на кількох окремих підприємствах 2010-х) pр. необхідно розглядати «зрізами», що виявляють певні тенденції еволюції мистецької частини заводів у взаємозв'язках. Типологія, стилістика і художні особливості українських фарфору та фаянсу у др. пол. ХХ ст. в умовах нових технологій і підтримки державою стрімко розвивалася. Вітчизняна тонка кераміка поступово змінювалася і в наступний період вже перебувала у постійних трансформаційних процесах [7, с. 400].

Починаючи з 1967 р., виготовлялися на Коростенському фарфоровому заводі численні тарілочки і флакончики, розписані різноманітними фігурками (переважно дитячими) в національному вбранні різних областей України.

На Довбинському порцеляновому заводі з 1967 р. розпочався випуск мініатюрних тарілочок. А в 1970 р. почали випускати дрібний посуд і на новому фарфоровому заводі в Тернополі. Це були мініатюрні баклажки оздоблені жанровими одно- чи двофігурними сценами на відповідний текст з українських народних пісень. Певною мірою до цих сувенірів-посудинок близька і фігурна сільничка, виготовлена на Будянському заводі. У ній також мали місце національний типаж, і форма посуду, і орнамент декору [1, с. 232].

Розвал СРСР приніс за собою занепад порцелянової промисловості зокрема й Україні. Порушилися традиційні виробничі та економічні зв'язки підприємств, виникли проблеми з постачанням сировини, технічно застаріло обладнання, втрачена підтримка держави і важлива галузь економіки й культури не витримала нових умов конкуренції.

\section{Jimepamypa:}

1. Бутник-Сиверський Б. Український Радянський сувенір / Бутник-Сиверський Б. Київ : Наукова думка, 1971. - 232 с. 2. Звягель «Баранівський фарфоровий завод визнано банкрутом» [Електронний ресурс] / О, Брюханов // Назва з титул. екрану. - Режим достуny:15.11.2013 // http://www.zvyagel.com.ua/?p=8397. 3. Кара-Васильєва Т. Твориі дивосвіту / Кара- Васильєва Т. - Київ : Рад. школа, 1984. - 175 с. 4. Укрінформ «Украӥнська пориеляна під загрозою зникнення» [Електронний ресурс] / Г. Лаба // Назва з титул. екрану. Режим достуny:19.08.2013 / http://www.ukrinform.ua/ukr/news/ukraiinska_ portselyana_pid_zagrozoyu_zniknennya_analitik_1858618. 5. Мистецтво Украӥни. Енциклопедія в $\overline{5}$ m. T. 1. - Київ. - 1991. 6. Теодорович Н. Историко-статистическое описание иерквей и приходов Вольнской епархии / Николай Теодорович. - Почаев. - 5 T. 1888. - 913 с. 7. Школьна О. Київський художній фарфор ХХ століття / Ольга Школьна. Київ : День Печати, 2011. - 400 с.: іл.. - Укр., pос. мовами. 8. Kostuch B. Polska Porcelana / Kostuch Bozena - Krakow. Kluszynski, 2013. - 213 s. 9. Szkurlat A.: Manufaktura porcelany $i$ fajansu w Korcu, / Anna Szkurlat - Warszawa., Zamku Krolewskiego, 2011 - 357s. 10. Ryszard S: Porcelana uzywana w Polsce. / Stanislaw Ryszard Krakow: Sztuk Pieknych, 1932. - 115 s. 11. Фарфор, украӥнське мистецтво «Завод Міклашевського» [Електронний ресурс] / Д. Сікорський// Назва з титул. екрану. - Режсим достуnу:20.09 2009// http://sikorskiy.com.ua/ blog/2009/09/20. 12. Федевич Л. Пориеляна Волокитенської мануфактури Андрія Міклашевського: каталог колекиії Сумського художнього музею/Людмила Федевич. - Суми. 2006. $-31 \mathrm{c}$. 